\title{
Karsinoma Hepatoselular pada Anak Usia 11 Tahun Laporan kasus
}

\author{
NP Veny Kartika Yantie, K Ariawati, IGN Sanjaya \\ Bagian Ilmu Kesehatan Anak Fakultas Kedokteran Universitas Udayana/Rumah Sakit Sanglah Denpasar, Bali
}

\begin{abstract}
Karsinoma hepatoselular merupakan tumor epitelial ganas pada hepar dan menempati urutan ketiga tumor hepar terbanyak pada anak. Telah diketahui bahwa terdapat hubungan antara karsinoma hepatoselular dengan infeksi hepatitis B kronik. Gejala awal tidak khas, dapat dikenali setelah tumor mencapai ukuran bermakna yaitu pada stadium lanjut sehingga diagnosis menjadi terlambat. Seorang anak laki-laki, usia 11 tahun dengan masa multilobus pada hepar, berobat dalam stadium lanjut sehingga tidak dapat dilakukan operasi. Dilakukan pencitraan abdomen dengan CT-scan dan evaluasi secara mikroskopis untuk memastikan diagnosis karsinoma hepatoselular. Hasil uji serologi terhadap infeksi hepatitis B menandakan hepatitis B kronik. Pasien mendapatkan kemoterapi siklus pertama dengan cisplatin dan doksorubisin. Prognosis pasien buruk, sehingga meninggal setelah satu setengah bulan didiagnosis. Sari Pediatri 2011;13(3):179-84.
\end{abstract}

Kata kunci: karsinoma hepatoselular, hepatitis B kronik, anak

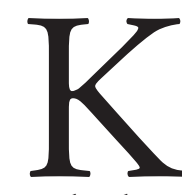

arsinoma hepatoselular merupakan tumor ganas primer pada hepar, yang ditemukan pada yang anak besar. ${ }^{1}$ Insidens tumor hepar 1\% dari semua neoplasma pada anak, dengan 1,4:1.000.000 setiap tahun pada anak usia $<16$ tahun. ${ }^{2}$ Karsinoma hepatoselular merupakan hasil akhir dari infeksi virus hepatitis B (HBV) atau hepatitis $\mathrm{C}(\mathrm{HCV})$, lebih sering terjadi pada remaja atau dewasa. Terdapat hubungan antara karsinoma

\footnotetext{
Alamat korespondensi:

Dr. Ni Putu Veny Kartika Yantie Bag/SMF Ilmu Kesehatan Anak FK UNUD RSUP Sanglah Denpasar. Jl. P Nias, telp/Fax 0361-244038, Denpasar
}

hepatoselular dengan infeksi hepatitis B dan ibu dengan seropositif $\mathrm{HBs} A g$, mengindikasikan terjadi transmisi HBV perinatal yang berkembang menjadi keganasan saat usia 7-8 tahun. ${ }^{1}$

Tanda dan gejala karsinoma hepatoselular sangat mirip dengan hepatoblastoma, namun anak dengan karsinoma hepatoselular terlihat lebih sakit dibandingkan hepatoblastoma. Pada pemeriksaan fisik didapatkan pembesaran masa pada abdomen. ${ }^{3}$ Diagnosis ditegakkan dengan pemeriksaan CT-scan, MRI dan atau biopsi hati. ${ }^{1}$ Perjalanan penyakit secara alami serta angka rata-rata kelangsungan hidup ditentukan oleh stadium saat pasien terdiagnosis. Penentuan stadium sangat penting untuk pilihan terapi yang tepat. ${ }^{4}$ Karsinoma hepatoselular merupakan tumor ganas dengan prognosis yang terburuk. ${ }^{2}$ 


\section{Laporan kasus}

Seorang anak laki-laki, usia 11 tahun, rujukan dari rumah sakit daerah. Tiga bulan sebelum masuk RS Sanglah Denpasar, pasien mengeluh mengalami nyeri perut di perut kanan atas kemudian menyebar di seluruh perut dan nyeri bertambah hebat pada tiga hari sebelum masuk rumah sakit. Tiga tahun yang lalu, pasien mengeluh mengalami perut membesar dan mengeras pada daerah perut kanan atas. Pasien juga mengeluhkan mual, napsu makan menurun dan badan bertambah lemah sejak tiga bulan sebelum masuk rumah sakit. Pasien terlihat kuning terutama pada mata sejak satu tahun sebelum masuk rumah sakit. Buang air besar dan kecil frekuensinya normal, namun warna bertambah gelap. Tidak didapatkan riwayat sesak maupun trauma.

Tidak pernah mendapatkan pengobatan khusus untuk penyakit tertentu. Tidak didapatkan riwayat terpapar radiasi, asap rokok, ataupun alkohol. Tidak ada angota keluarga lain yang mengalami gejala serupa. Status titer HBsAg pada kedua orangtua positif. Riwayat imunisasai dasar pasien lengkap sesuai program pemerintah.

Pada pemeriksaan fisik didapatkan anak sadar, terlihat lemah, tanda vital baik, dengan gizi kurang. Konjungtiva tidak pucat, sklera ikterik. Telinga, hidung, tenggorokan, jantung dan paru dalam batas normal. Abdomen terlihat distensi, bising usus normal. Dijumpai hepatomegali berlobus-lobus, padat, lien sulit dinilai (Gambar 1). Tidak didapatkan tanda asites dan pada palpasi didapatkan turgor normal. Limfadenopati regio aksila dan inguinal kanan dan kiri, diameter \pm 1 $\mathrm{cm}$, padat, multipel, terfiksasi, tidak merah dan tidak nyeri. Akral teraba hangat, perfusi perifer normal, tidak didapatkan edema maupun sianosis.

Pemeriksaan darah lengkap, serum elektrolit, fungsi ginjal, menunjukkan nilai dalam rentang normal. Pada pemeriksaan fungsi hati didapatkan bilirubin total $1,421 \mathrm{mg} / \mathrm{dL}$; bilirubin indirek 0,782 $\mathrm{mg} / \mathrm{dL}$; bilirubin direk $0,639 \mathrm{mg} / \mathrm{dL}$; alkali fosfatase 302,8 u/l; SGOT 352 u/l; SGPT 141 u/l; gamma GT $463 \mathrm{u} / \mathrm{l}$; protein total 8,035 g/dL; albumin 4,009 g/ $\mathrm{dL}$; kolesterol $610,7 \mathrm{mg} / \mathrm{dL}$; trigliserida $246,2 \mathrm{mg} /$ dL. HBs Ag 16,42 (positif); AFP 261,24 UI/ml; anti-HBc reaktif; anti-HBc IgM non reaktif; $\beta$-HCG $<0,01 \mathrm{mIU} / \mathrm{ml}$; HBV-DNA $1.8 \times 10^{2} \mathrm{IU} / \mathrm{ml} ; \mathrm{HBe}$ $\mathrm{Ag}$ non reaktif; anti-HCV non reaktif. Tumor marker menunjukkan CEA 6,3 ng/mL.
Pemeriksaan foto radiologi dada menunjukkan gambaran normal (Gambar 2). Pemeriksaan CT-scan abdomen menunjukkan gambaran splenomegali dan terdapat masa solid di lobus kanan dan kiri dengan area nekrosis mengarah pada karsinoma hepatoselular (Gambar 3).

Pemerikaan patologi (FNAB) dengan pengecatan diff quick dan papaniculou menunjukkan gambaran hiperselular dengan sel anaplastik trabekular, merupakan suatu tumor ganas mengarah pada karsinoma hepatoselular.

Berdasarkan manifestasi klinis serta pemeriksaan penunjang, pasien didiagnosis dengan karsinoma hepatoselular stadium IIIB, hepatitis B kronik, dan gizi kurang. Mengingat stadium penyakit telah lanjut, masa pada hepar tidak dapat dioperasi.

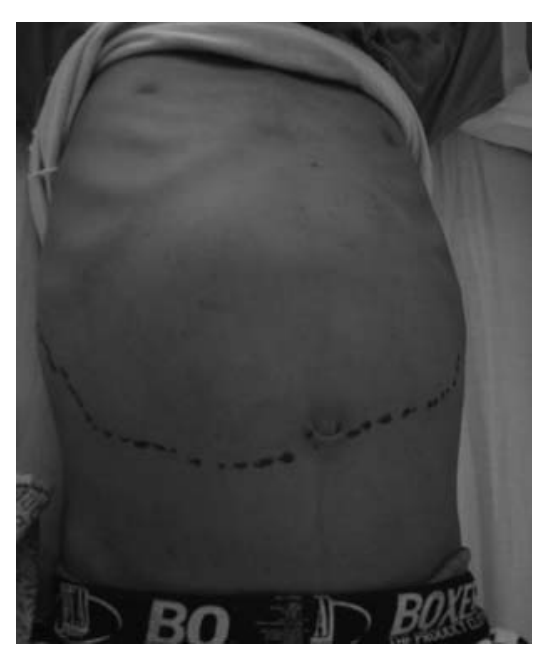

Gambar 1. Masa abdomen saat masuk rumah sakit

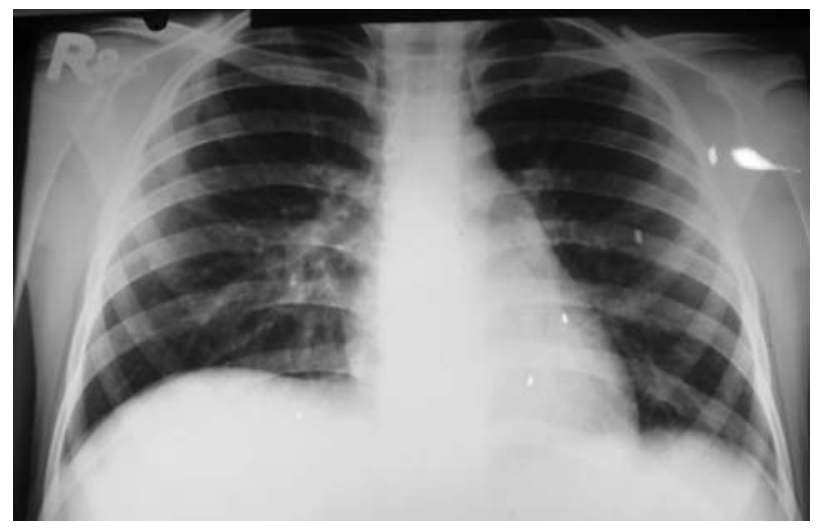

Gambar 2. Gambar radiologi dada saat awal masuk rumah sakit 


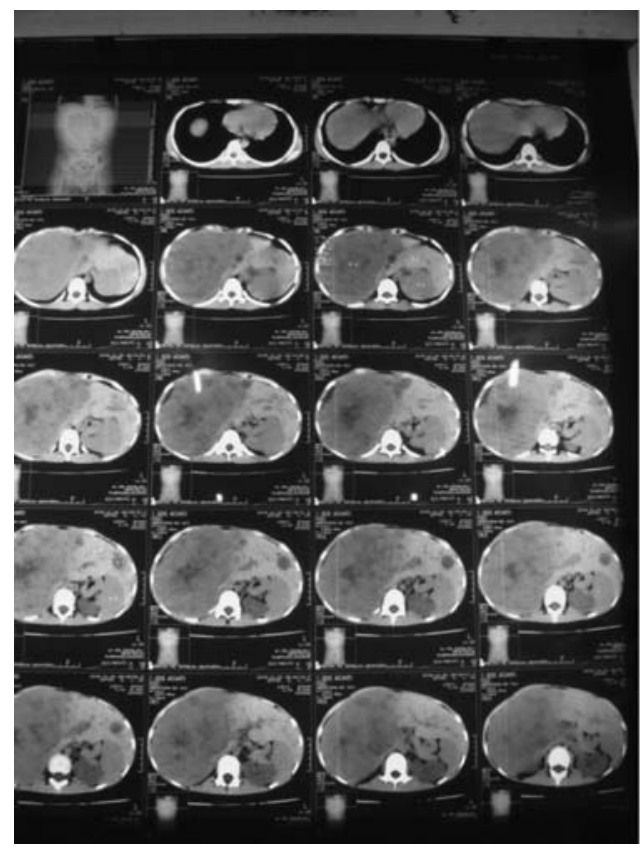

(a)

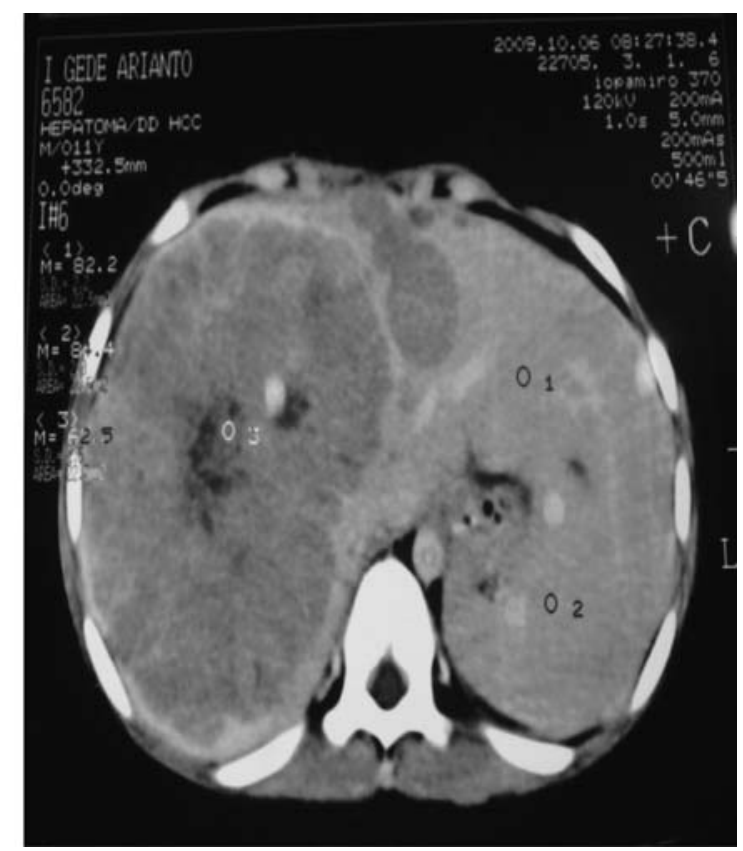

(b)

Gambar 3. Gambar CT-scan abdomen dengan kontras $(\mathrm{a}+\mathrm{b})$

Pasien mendapat kemoterapi cisplatin $20 \mathrm{mg} / \mathrm{m}^{2}$ dan doksorubisin $40 \mathrm{mg} / \mathrm{m}^{2}$ serta pemberian nutrisi berupa bubur dan makanan cair. Selama pemberian kemoterapi siklus pertama, tidak didapatkan efek samping dan direncanakan untuk siklus berikutnya pada tiga minggu kemudian. Namun dua minggu setelah kemoterapi, pasien meninggal dunia. Tata laksana untuk hepatitis B kronik direncanakan pemberian lamivudin $3 \mathrm{mg} / \mathrm{kg} / \mathrm{kali}$ (dosis maksimal $100 \mathrm{mg} /$ hari).

\section{Pembahasan}

Insiden tumor hepar 1\% dari semua neoplasma pada anak, dengan 1,4:1.000.000 setiap tahun yang terjadi pada anak usia $<16$ tahun. ${ }^{2}$ Karsinoma hepatoselular merupakan tumor ketiga terbanyak pada tumor hepar, $65 \%$ kasus pada anak berusia $>10$ tahun. ${ }^{1}$ Lebih sering mengenai anak laki-laki dibandingkan perempuan. ${ }^{3}$ Pasien yang dilaporkan adalah anak laki-laki berusia 11 tahun.

Secara umum, karsinoma hepatoselular disebabkan karena interaksi yang kompleks antara faktor genetik dan lingkungan. Insiden meningkat pada populasi karier infeksi hepatitis B (HBV). Terdapat hubungan
(80\%) antara karsinoma hepatoselular dengan infeksi hepatitis B kronik pada pasien dewasa dan dapat pula mulai berkembang sejak usia anak-anak. ${ }^{5}$ Penelitian di Taiwan menunjukkan anak usia 8-16 tahun dengan karsinoma hepatoselular menunjukkan serologi yang positif terhadap HBV dan $70 \%$ berasal dari ibunya. Insiden seropositif dari HBsAg lebih banyak pada hepatoselular dibandingkan varian fibrolamelar. Insiden karsinoma 75\% meningkat pada pasien nonalkoholik, perokok, dan paparan aflatoksin. Faktor risiko lain yang dicurigai berhubungan adalah diet, obesitas, diabetes dan resistensi insulin, penggunaan kontrasepsis oral, serta kelebihan zat besi. ${ }^{6}$ Faktor predisposisi pada kasus yang kami laporkan adanya seropositif HBsAg dari orangtua sedangkan faktor lain disangkal.

Karsinoma hepar merupakan tumor epitel ganas. Karsinoma hepatoselular tidak memiliki tanda atau gejala awal. Pada kenyataannya, tidak didapatkan gejala awal sampai tumor membesar dengan ukuran yang bermakna. Setelah stadium lanjut karsinoma hepatoselular akan bergejala dan terdeteksi. Manifestasi klinis berupa masa besar, mudah diraba di daerah kanan atas atau pembesaran yang menyeluruh pada abdomen, penurunan berat badan, anoreksia, muntah, nyeri abdomen, pucat, ikterus, dan ascites. 
NP Veny Kartika Yantie dkk: Karsinoma hepatoselular pada anak

Tabel 1. Stadium tumor ganas hepar

\begin{tabular}{|c|c|}
\hline Stadium & Kriteria \\
\hline Stadium I & Reseksi komplit saat diagnosis \\
\hline Stadium II & $\begin{array}{l}\text { Reseksi total kasar dengan terdapat sisa secara mikroskopik, tidak terdapat keikutsertaan } \\
\text { limfonodi, tidak terdapat tumor pada lien. } \\
\text { a. Residual di hepar } \\
\text { b. Residual ekstrahepatik }\end{array}$ \\
\hline Stadium III & $\begin{array}{l}\text { Residual nyata } \\
\text { a. Reseksi tumor komplit, namun terdapat keikutsertaan nodal atau tumor pada lien. } \\
\text { b. Reseksi tumor tidak komplit (hanya untuk biopsi) }\end{array}$ \\
\hline Stadium IV & $\begin{array}{l}\text { Matastase jauh } \\
\text { a. Tumor primer dapat direseksi komplit } \\
\text { b. Tumor primer tidak direseksi secara komplit. }\end{array}$ \\
\hline
\end{tabular}

Sumber: Hodder HJ dan Keene $\mathrm{N}^{3}$

Penyebaran metastasis dapat ditemukan pada paru, jarang pada tulang, otak maupun sumsum tulang. Apabila ditemukan tanda peritoneal, hal tersebut menunjukkan perforasi tumor. ${ }^{2}$ Pada kasus kami, terdapat pembesaran perut sejak tiga tahun sebelum masuk rumah sakit, nyeri perut sejak tiga bulan sebelum masuk rumah sakit, anoreksia, penurunan berat badan dalam waktu singkat, serta lemah. Pada pemeriksaan fisik ditemukan masa solid pada abdomen atas dan limfadenopati.

Infeksi hepatitis B dapat dievaluasi dengan pemeriksaan serologi (HBsAg, $\mathrm{HBeAg}$, anti-HBe, anti-HBc/IgM). Hepatitis B kronik menunjukkan kadar HBsAg tinggi selama lebih dari 6 bulan dalam darah. Terdapat tiga fase dalam perjalanan alamiah infeksi HBV kronik berdasarkan status serum HBeAg dan HBV DNA, pertama yaitu adanya fase seropositif $\mathrm{HBeAg}$ (replikasi yang tinggi dari HBV) dengan kadar ALT (alanine aminotransferase) yang normal; fase serokonversi $\mathrm{HBe}$ (pembersihan HBV) dengan peningkatan kadar ALT; dan fase pasca serokonversi $\mathrm{HBe}$ (HBV rendah atau tidak mengalami replikasi). Anak dengan karier HBsAg pada umumnya disertai seropositif $\mathrm{HBeAg}$ dan kadar ALT normal. Seropositif $\mathrm{HBeAg}$ 80\%-85\% pada karier HBsAg anak dengan usia $<15$ tahun. Dengan pertambahan usia pembersihan HBV DNA dan HBeAg akan memasuki fase serokonversi $\mathrm{HBe}$, pada akhirnya akan kehilangan $\mathrm{HBeAg}$ dan menjadi seropositif anti-HBe. ${ }^{7,8}$ Kasus kami menunjukkan infeksi hepatitis B kronik fase 2, dan tidak terdapat infeksi hepatitis $\mathrm{C}$.

Evaluasi karsinoma hepatoselular yaitu pemeriksaan laboratorium, CT-scan atau MRI abdomen atau biopsi.
Tabel 2. The Okuda Staging System

\begin{tabular}{lll}
\hline Kategori & Nilai 0 & Nilai 1 \\
\hline Masa tumor & $<50 \%$ dari hepar & $\geq 50 \%$ dari hepar \\
Albumin $(\mathrm{g} / \mathrm{dL})$ & $>3$ & $\leq 3$ \\
Bilirubin $(\mathrm{mg} / \mathrm{dL})$ & $<3$ & $\geq 3$ \\
Asites & Ya & Tidak \\
Stadium I & Poin 0 & \\
Stadium II & Poin 1-2 & \\
Stadium III & Poin 3-4 & \\
\hline
\end{tabular}

Sumber: Blum $\mathrm{HE}^{10}$

Pada CT-scan atau MRI abdomen ditemukan lesi dengan penebalan arteri pada hepar pasien dengan sirosis. Terdapat pembentukan vaskuler baru pada nodul karsinoma. Gambaran tersebut memiliki sensitivitas $80 \%$ dengan spesifisitas 95\%-100\%. Lesi $<2 \mathrm{~cm}$, memerlukan biopsi hati. ${ }^{9}$ Berdasarkan hasil radiologis dada, CT-scan abdomen dengan kontras dan biopsi hepar (FNAB) didiagnosis ditegakkan sebagai karsinoma hepatoselular dan tidak dijumpai metastasis.

Diagnosis definitif ditegakkan dengan pemeriksaan histopatologis melalui biopsi, termasuk tumor, batas reseksi dan limfonodi. Stagging sangat penting untuk pemilihan terapi. Stagging system berdasarkan perluasan tumor, untuk menentukan operasi (Tabel 1). The Okuda Stagging System menggambarkan 5 sistem yang ditujukan untuk diagnosis dan prognosis (Tabel 2), selain itu terdapat pula klasifikasi TNM dengan modifikasi oleh Union International Contre Cancer (UICC), klasifikasi Barcelona Clinic Liver Cancer (BCLC) (Tabel 3), dan skor Cancer of the Liver 
NP Veny Kartika Yantie dkk: Karsinoma hepatoselular pada anak

Tabel 3. Klasifikasi Barcelona Clinic Liver Cancer (BCLC)

\begin{tabular}{lllll}
\hline Stadium & PST* & $\begin{array}{l}\text { Karsinoma } \\
\text { hepatoselular (n) }\end{array}$ & Okuda & Fungsi hepar \\
\hline A: awal & & I & I & Tanpa ph, ${ }^{* *}$ bil normal \\
A1 & 0 & I & I & Ph,** bil normal \\
A2 & 0 & I & I & Ph,** bil meningkat \\
A3 & 0 & $3,<3 \mathrm{~cm}$ & I-II & Child pugh A-B \\
A4 & 0 & $>3 \mathrm{~cm}$ & I-II & Child pugh A-B \\
B: intermediate & 0 & Invasi vaskular & I-II & Child pugh A-B \\
C: lanjut & 1 & metastase jauh & & \\
& & semua & Child pugh C \\
D: akhir & $3-4$ & &
\end{tabular}

*Performance status; ${ }^{* *}$ portal hypertension

Sumber: Blum HE ${ }^{10}$

Tabel 4. Skor Cancer of the Liver Italian Program (CLIP) 10

\begin{tabular}{llll}
\hline Kategori & Poin 0 & Poin 1 & Poin 2 \\
Child Pugh & A & B & C \\
\hline Masa & Soliter $/<50 \%$ & Multifokal $/<50 \%$ & Multifokal $/>50 \%$ \\
AFP $(\mathrm{ng} / \mathrm{ml})$ & $<400$ & $\geq 400$ & \\
Trombosis vena porta & Tidak & Ya & \\
\hline
\end{tabular}

Kelangsungan hidup pasien menurut Skor CLIP

\begin{tabular}{llll}
\hline Skor CLIP & Median (bulan) & 1 tahun $(\%)$ & 2 tahun $(\%)$ \\
\hline 0 & 36 & 84 & 65 \\
1 & 22 & 66 & 45 \\
2 & 9 & 45 & 17 \\
3 & 7 & 36 & 12 \\
$4-6$ & 3 & 9 & 0 \\
\hline
\end{tabular}

Sumber: Blum HE ${ }^{10}$

Italian Program (CLIP) score (Tabel 4). Tidak terdapat klasifikasi yang lebih baik dibandingkan klasifikasi lain. Perjalanan penyakit dan kelangsungan hidup pasien dengan karsinoma hepatoselular tergantung pada stadium saat didiagnosis. Pasien dengan skor CLIP atau stadium Okuda I mempunyai median kesintasan 23-69 bulan, sedangkan skor CLIP 3-5 atau Okuda stadium III mempunyai median kesintasan 1-14 bulan. ${ }^{9}{ }^{, 10}$ Pada kasus kami, stadium klinis telah berada dalam IIIB, namun pada stadium Okuda berada pada stadium II, dengan skor CLIP berjumlah tiga dengan median kelangsungan hidupnya adalah 7 bulan.

Tata laksana karsinoma hepatoselular dapat berupa operasi (reseksi, transplantasi hepar), kemoterapi (intervensi perkutan, transarteri, obat-obatan) dengan cisplatin/ interferon doksorubisin (adriamisin) 5fluorourasil (5-FU). Secara umum prognosis karsinoma hepatoselular buruk dan secara umum mendapatkan perawatan paliatif. Angka kelangsungan hidup dalam lima tahun 10\% dengan rerata 5,3 bulan. Pasien kami tidak dapat lagi dioperasi dan hanya mendapatkan kemoterapi satu siklus. Pasien meninggal dalam 1 tahun 15 hari setelah didiagnosis.

\section{Kesimpulan}

Karsinoma hepatoselular merupakan tumor ganas hepar dengan insiden 1\% dari seluruh neoplasia anak, ini disebabkan karena interaksi antara faktor genetik dan lingkungan. Infeksi hepatitis B kronik merupakan predisposisi tersering dari karsinoma hepatoselular. Tumor hepar tidak mempunyai tanda awal yang khas, sehingga ditemukan pada stadium lanjut. Pilihan 
terapi untuk karsinoma ini terbatas yaitu terapi pembedahan (untuk tumor kecil) sedangkan terapi tambahan dapat berupa kemoterapi berupa PIAF (cisplatin/ interferon/doksorubisin [adriamisin]/5fluorourasil [5-FU]). Prognosis secara umum adalah buruk karena keterlambatan diagnosis dan tingginya derajat keganasan.

\section{Daftar pustaka}

1. Stocker JT. Hepatic tumor in children. Dalam: Suschy FJ, Sockol RJ, Balistreri WF, penyunting. Liver disease in children. Philadelphia: Lippincott Williams \& Wilkins; 2004.h.915-43.

2. Imbach P. Hepatic tumor. Dalam: Imbach P, Kuhne T, Arceci R, penyunting. Pediatric oncology. Berlin: Springer; 2004.h.187-91.

3. Hodder HJ, Keene N. Childhood cancer. Edisi kedua. USA: O’Reilly \& Associates, Inc.; 2002.h.182-8.
4. Nouso K, Kuwaki K, Ito YM, Kobayashi Y, Nakamura S, Ohashi Y, dkk. Prognostic factors and treatment effects for hepatocellular carcinoma in child cirrhosis. British J of Cancer 2008;98:1161-5.

5. Marreroa CR, Marrero JA. Viral hepatitis and hepatocellular carcinoma. Arch Med Research 2007;38:612-20.

6. Chuang SC, Vecchia CL, Boffeta B. Liver cancer: descriptive epidemiology and risk factors other than HBV and HCV infection. Cancer Letters 2009;286:9-14.

7. Bortolotti F, Jara P, Crivellaro C, Hierro L, Cadrobbi P, Frauca E, dkk. Outcome of chronic hepatitis B in caucasian children during a 20 -year observation period. J Hepatol 1991;29:184-90.

8. Chang MH. Hepatitis B infection. Seminars in fetal \& neonatal medicine 2007;12:160-7.

9. Tabor E. Hepatocellular carcinoma: global epidemiology. Digest Liver Dis 2001;33:115-7

10. Blum HE. Treatment of hepatocellular carcinoma. Best Practice \& Research Clin Gastroenterol 2005;19:12945. 